\title{
䊬菌ホスファターゼに関する研究, とくに澱粉分解を中心に
}

グルコアミラーゼは $\alpha-1,6$ 結合も切断でき, 理論的には澱粉を 100 \% クルコースに分解できる筈である。ところが馬鈴蔈澱粉などは約 90 \% しか分解されずその一因として䗲含荁が大きくクローズアップされ て来た。ホスファターセの共同作用によって完全加水分解が行われるこ とは清酒醇造など, 特に酳素郕仕込みにとっても多くの示唆を含んでい る。簕者はさらに本ホスファターゼの生産, その核酸系呈味物紫製造へ の応用にまで言及している。

\section{九州大学車学部食䊓化学工学科}

上田誠之助

溉粉中にリン酸が含まれていることはすでは 1914 年 Samec ら ${ }^{1,2}$ によって示された。彼らは馬鈴著殷粉溶液 を電気泳動にかけ,リン酸を含む成分とリン酸を含まぬ 区分とに分けることに成功した。また Posternak ${ }^{3)}$ は 1935 年穀類筂粉に含まれるリン酸はほとんどリン脂質 の形であって，それは測粉をエーテルや熱アルコールで 処理することによって，瑖粉から除去できるか，馬鈴薯 澱粉など根茎澱粉に含まれるリン酸は上記の操作では除 去できず，澱粉の加水分解によってグルコースー6-リン 酸がえられることから，根茎澱粉ではりン酸基は測粉中 のグルコースの 6 位の炭素にエステル結合していると報 告した。また彼は4) 馬鈴薯澱粉糊に膵臓の $\alpha$-アミラーゼ, または麦芽の $\alpha$-と $\beta$-アミラーゼを徹底的に作用させ， グルコース基 4 個よりなるマルトテトラオースリン酸, グルコース基 6 個よりなるマルトヘキサオースリン酸を えて, この場合もりン酸がグルコースの 6 位の炭素にグ ルコースー6-リン酸の形で澱粉に結合していることを証 明した。このことから彼は馬鈴薯澱粉のリン酸がアミラ 一ゼの作用を阻止したものと考えた。

1942 年 $\mathrm{Schoch}^{\text {) }}$ はブタノールを用いて澱粉を直鎖分 子のアミロースと分枝構造をるつアミロペクチンに分画 する方法を考案し，馬鈴薯澱粉と玉蜀乘澱粉とを比較し たところ，第1表に示すように馬鈴薯澱粉ではリン酸が アミロペクチン区分に集まるが，玉蜀㯟溊粉ではいずれ の区分にもほとんどリン酸が含まれていないことを明ら かにし, Posternak の研究を確認した。さらに最近,
福井6)により新しい手法をもとにこのことは再確認され た。

$\mathrm{Myrbäck}^{7)}$ む馬鈴薯測粉糊を植物の $\beta$-アミラーゼで 分解し，限界デキストリン中に筑粉の全リン酸が移行す ることから，限界デキストリン生成の原因に $\alpha-1,6-ク ゙$ ルコシド結合のほかにリン酸結合をす考元た。また馬鈴 薯澱粉糊を $\alpha$-アミラーゼで分解し，約 $13 \%$ 分解（還元 力の増加から）の時点で生成デキストリンをアルコール で分画したところ，第 2 表にみられるように，分子量の 大きなデキストリン画分にリン酸が集まることから，彼

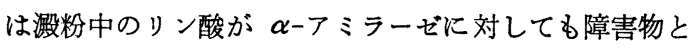
して作用するのだろうと推論した。近年, 檜作ら ${ }^{8)}$ は馬

第1表 馬鈴薯澱粉と玉蜀禁澱粉とに扣ける燐酸の 分布

(T. J. Schoch 1942)

\begin{tabular}{|c|c|c|c|}
\hline 馬 鈴粪澱 粉 & 燐 & 玉蜀 乘溦粉 & 燐 \\
\hline 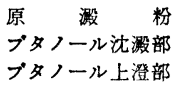 & $\begin{array}{l}0.072 \\
0.0103 \\
0.079\end{array}$ & 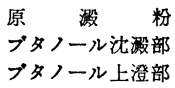 & $\begin{array}{l}0.0153 \\
0.0088 \\
0.0107\end{array}$ \\
\hline
\end{tabular}

第 2 表 麦芽 $\alpha$-amylase で馬鈴薯澱粉を $13 \%$ 水解 したときの $\alpha$-dextirin

(K. H. Meyer 1948)

\begin{tabular}{|c|c|c|c|c|c|c|c|}
\hline 区 & 分 & 収 & 量 \% & 沃素反応 & 分 & 子 量 & 橉 \\
\hline PD & I & & 1.24 & 紫 & & 4,100 & 0.267 \\
\hline$P D$ & II & & 19.02 & 褐 & & 4,100 & 0.143 \\
\hline$P D$ & III & & 11.09 & 赤 & & 2,940 & 0.112 \\
\hline PD & IV & & 4.64 & 黄 & & 1,910 & 0.129 \\
\hline PD & $\mathrm{V}$ & & 12.14 & 無 & & 1,150 & 0.048 \\
\hline$P D$ & VI & & 3.11 & 無 & & 1,090 & 0.017 \\
\hline
\end{tabular}


第 3 表 limit dextrin のアルコール分劃 ${ }^{10}$

\begin{tabular}{|c|c|c|c|c|c|}
\hline 区 & & 分 & I & II & III \\
\hline alcohol & & $\%$ & 40 & 60 & 80 \\
\hline 収 & & 量 $\mathrm{g}$ & 1.0 & 0.8 & 0.4 \\
\hline 全 & 糖 & 分 \% & 92.9 & 92.0 & 67.5 \\
\hline 直 接 & 還 & 力 $\%$ & - & 1.6 & 4.1 \\
\hline 有 & 機 & 矮 \% & 0.16 & 0.28 & 0.28 \\
\hline $\mathrm{CHO}$ 基 & 加 & 重合度 & 101 & 55 & 16 \\
\hline 有機燐 & 当りの & 直合度 & 106 & 56 & 46 \\
\hline
\end{tabular}

鈴薯澱粉中のリン酸がグルコースの 6 位の炭素のほか, 2 位あるいは 3 位の炭素とも結合していることを報告し ている。

一方, 私共は黑棅菌 Aspergillus awamori var. kawachii のグルコアミラーゼが糯米濒粉や，グルコー ゲンをほとんど完全にグルコースに分解でき，このアミ

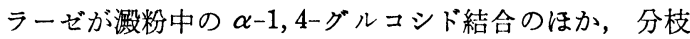

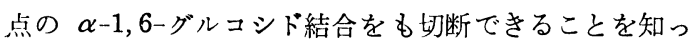
だ) が，このグルコアミラーゼを馬鈴薯澱粉に作用させ たところ，約 $90 \%$ しか分解されず，沃素反応青紫色の 限界デキストリンを生じた。また馬鈴薯澌粉を Schoch の方法（ブタノール沈澱法）でアミロースとアミロペク チンに分画し，それぞそにグルコアミラーゼを作用させ たところ，アミロースはほとんど完全にグルコースに加 水分解されるのに，アミロペクチンは約 $85 \%$ しか分解

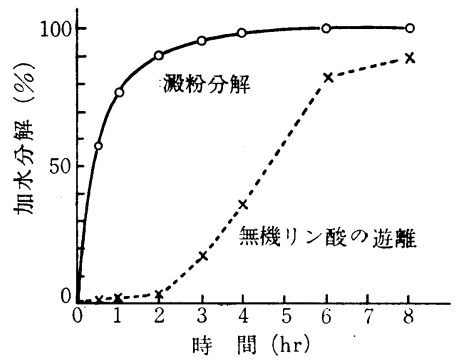

第1図 馬鈴薯澱粉の粗グルコアミラーゼと

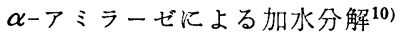

されないことを知った。それ故アミロペクチン区分に含 まれるリン酸がグルコアミラーゼの作用に対し障害物と なっている可能性が考えられた。

そこでグルコアミラーゼにより生じた馬鈴薯澱粉の限 界デキストリンをアルコールで分画したところ，第 3 表 にみられるように, グルコース重合度 ( $\overline{\mathrm{DP}}$ と略す) 100, 50, 20 位のデキストリンがえられ， DP $100 ， 50$ のデキ ストリンはそれぞれ 1 分子のリン酸を含有していた。そ れ故, 恐らく洆粉中のリン酸がグルコアミラーゼ作用に 対し，障害となっているものと考えた。ところがこのグ ルコアミラーゼに $\alpha$-アミラーゼを共同させたところ, 第 1 図に見られるように，馬鈴薯䬺粉は無機リン酸を遊 離しつつ，ほとんど完全にグルコースに加水分解される ことがわかった10)。そこで，グルコアミラーゼと $\alpha$-ア ミラーゼのいずれの区分にホスファターゼ活性があるか 調べたところ，グルコアミラーゼ区分にホスファターゼ 活性が存在することを知っだ11。しかしながらホスファ ターゼ活性をもつグルコアミラーゼ区分単独では馬鈴薯 澱粉に作用しても無機りン酸の遊離はみられないから， このホスファターゼは $\overline{\mathrm{DP}}$ の小さな含リンデキストリン にしか作用しえないものと考えられる。

そこで，グルコアミラーゼ区分中に含まれるホスファ ターゼの性質を調べたところ，第 4 表，第 5 表に示され るよらに, このホスファターゼはグルコースー6-リン酸 によく作用し, 至適 $\mathrm{pH} 3.4$ 付近で耐酸性強く, 従来 Swanson ${ }^{12)}$ が肝蔵からえたホスファターゼより著しく

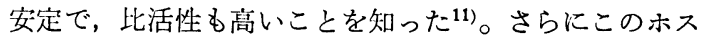
ファターゼの精製を試み，第 2 図に見られるように DEAE-セルロースカラムで 3 のピークに分かれた ${ }^{13)} 。 そ$ のらち 1 ピークが最も活性が大きく，このホスファター

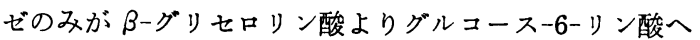
の活性が大であった。また第 3 図にみられるように至適

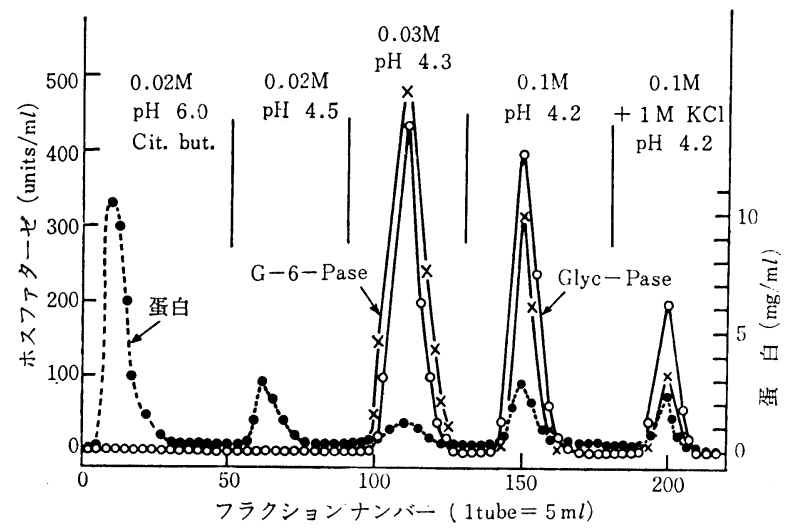

第2図ホスファターゼの DEAE セルロースカラムでの純化 ${ }^{13)}$ 
第 4 表 各 種 $\mathrm{pH}$ の 影 響

(30，30分間に䢍離する $\mathrm{Pr} /$ 反応液 $1 \mathrm{ml}$ )

\begin{tabular}{|c|c|c|c|c|}
\hline 基 & 2.6 & 3.4 & 4. 0 & 4.6 \\
\hline グリセ口橉酸 & 7.8 & 8.3 & 7.4 & 5.2 \\
\hline グリコースー6-燐酸 & 9.0 & 12.0 & 11.2 & 6.0 \\
\hline グルコースー1-燐酸* & 13.5 & 14.8 & 12.0 & 9.7 \\
\hline
\end{tabular}

グリセロ㶴酸，グルコースー1ー橉酸を基睤とした場合には spontaneous の分解を差し引いた。

*醉素液に phosphorylase の活性なくPの遊離はすべて phospha・ taseに由来した。

第 5 表 麬慗と振燙培養との比較 ${ }^{11)}$ $\left(30^{\circ}, 30\right.$ 分間に㖣離する $\mathrm{Pr} /$ 空美 $1 \mathrm{mg}$ )

\begin{tabular}{|c|c|c|c|}
\hline 䤊 源 & \begin{tabular}{|l} 
謷数抽出液 \\
Pr/全咥素 \\
$1 \mathrm{mg}$
\end{tabular} & 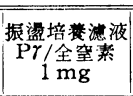 & $\begin{array}{c}\text { 脑 } \\
\text { (Swanson } 9 \text { data) } \\
\text { Pr/蛋白態空素 } \\
1 \mathrm{mg}\end{array}$ \\
\hline グリセ口橉酸 & 125.0 & 253.0 & 12.9 \\
\hline グルニースー6-燐酸 & 244.0 & 426.0 & 56.0 \\
\hline グルコースー1 -燐酸* & 184.0 & 524.0 & 4.9 \\
\hline ヘキソース二燐酸 & 115.0 & 145.0 & 0 \\
\hline
\end{tabular}

グリセロ燐酸,グルコースー1一燐酸、ヘキソース二燐酸を基質にした場 合には spontaneous の分解を差し引いた。

*醉素液に phosphorylase の活性なくPの遊離はすべて phosphatase に由来した。
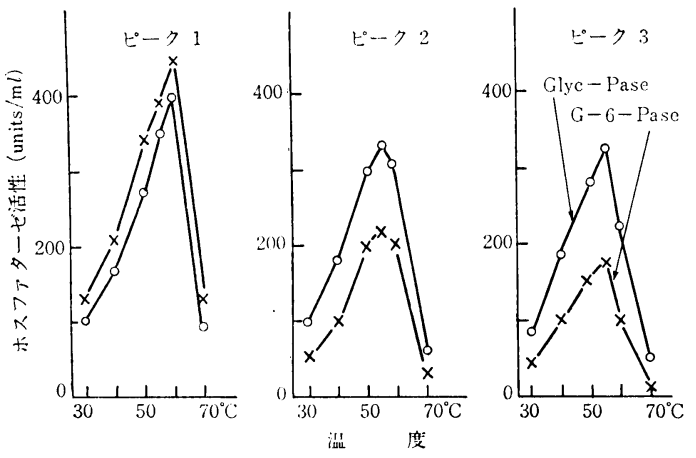

第 3 図 3 種ホスファターゼの至適温度 ${ }^{13)}$
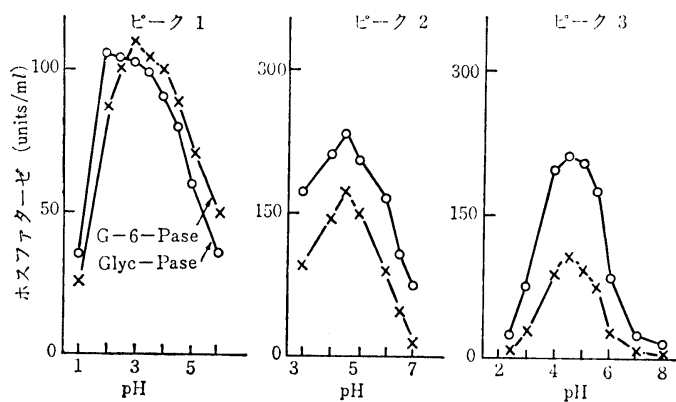

第 4 図 3 種ホスファターゼの至適 $\mathrm{pH}$

温度はいずれのホスファターゼも $55^{\circ} \mathrm{C}$ 付近にあり, 至 適 $\mathrm{pH}$ は第 4 図に示されるように，ピーク 1 のホスファ

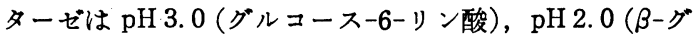
リセロリン酸）付近にあるが，ピーク 2 および 3 はどち

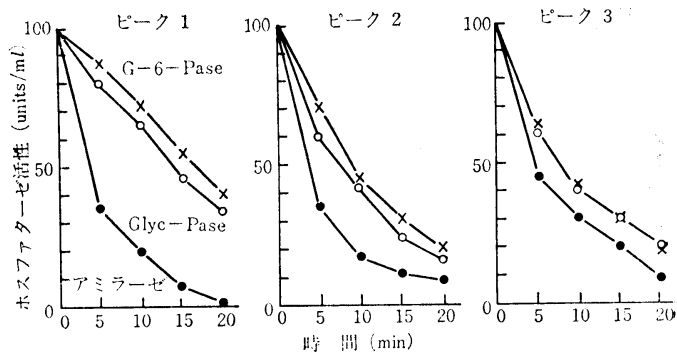

第 5 図 $65^{\circ} \mathrm{C} \mathrm{pH} 4.3$ での熱処理でのホスファター ゼとアミラーゼ挙動

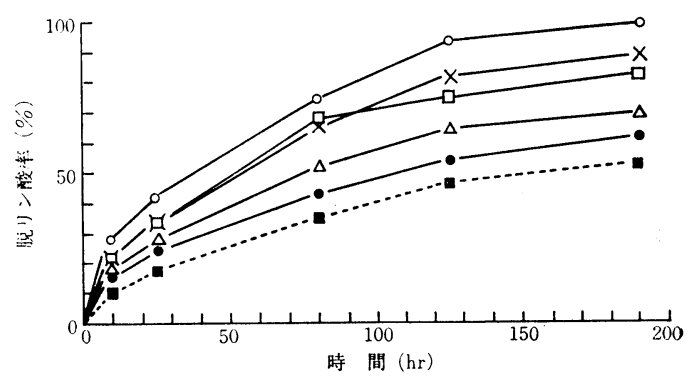

第 6 図 ホスファターゼの各種含リンデキストリン への作用
$\mathrm{ODP}: 3-4$
$\times \overline{\mathrm{PD}}: 6-7$
$\square \mathrm{DP}: 4-5$
$\triangle \overline{\mathrm{DP}}: 7-8$
ОDP : 7-8
DP : 9-10

らの基質に対しても $\mathrm{pH} 4.5$ 付近にあった。第 5 図から 明らかなよらにピーク 1 のみ, $65^{\circ} \mathrm{C} \mathrm{pH} 4.320$ 分の熱処 理でアミラーゼフリーのホスファターゼとすることがで きた。

一方，各種アミラーゼを使用し，馬鈴薯澱粉から $\overline{\mathrm{DP}}$ の異なる含リンデキストリンを調製し，上記のアミラー ゼフリーのホスファターゼを作用させたところ，第 6 図 にみられるように， $\overline{\mathrm{DP}}$ の大きな含リンデキストリンほ ど，脱りン酸がおこりにくいことがわかった。また細菌 $\alpha$-アミラーゼを馬鈴薯澱粉に作用させて調製した DP 9 〜10 の含リンデキストリンにホスファターゼフリーの グルコアミラーゼを作用させたところ，約 $60 \%$ 分解し たところで分解が止まり，それにアミラーゼフリーのホ スファターゼを添加させたところ，無機りン酸の遊離を 伴ないつつ，デキストリンの完全分解がおこることを知 った。（第 7 図）またこの含リンデキストリンは細菌 $\alpha$ アミラーゼによる再分解，または $\beta$-アミラーゼによる 分解で，ほんの $20 \%$ しか分解されず，麦芽の $\alpha$-执よ び $\beta$ ーアミラーゼの混合系によって約 $60 \%$ 分解され, $\overline{\mathrm{DP}}$ 約 4 の含リンデキストリンが残った。（第 8 困）また ピーク 1 , ピーク 2 , ピーク 3 のいずれが含リンデキス トリンからの脱リン酸反応の活性が強いかを調べるため, 


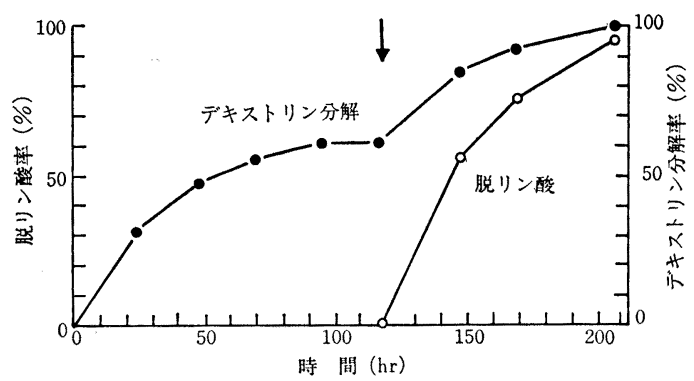

第 7 図 含リンデキストリンの分解 ${ }^{14)}$

反応系 : グルコアミラーゼ $(20$ 単 位 $/ \mathrm{m} l) 1 \mathrm{~m} l, \overline{\mathrm{DP}}$ 9-10の含り ンデキストリンのバリウム塭 $100 \mathrm{mg}$ を含む基質溶液 $4 \mathrm{~m} l, 0.5 \mathrm{~N}$ 酭 酸緩衝液 $5 \mathrm{~m} l(\mathrm{pH} 4.0)$ 。矢印の点でホスファターゼ $(10$ 単位 $/ \mathrm{m} l)$ $1 \mathrm{~m} l$ を加える

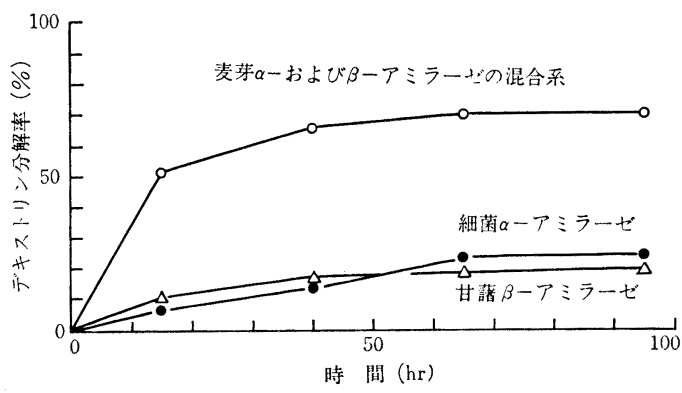

第 8 図各種アミラーゼによる含リンデキストリン の分解 ${ }^{14)}$

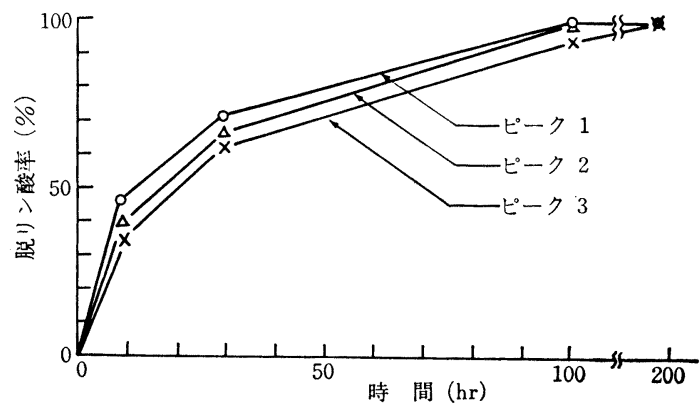

第 9 図含リンデキストリンの脱リン酸に際しての ピーク $1,2,3$ の比較

それぞれ G-6-pase 活性 60 単位 $/ \mathrm{m} l \alpha-\boldsymbol{~}$ $/ \mathrm{m} l$ グルコアミラーゼ活性 10 単位 $/ \mathrm{m} l$ 亿調整

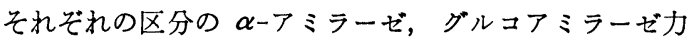
価を， $\alpha$-アミラーゼ，グルコアミラーゼをそれぞれに加 えて一定アミラーゼ力価 (10 単位 $/ \mathrm{m} l$ )にしたのち, $\overline{\mathrm{DP}}$ 3-4 の含燐デキストリンに作用させたところ，第 9 図に みられるように 3 者の間に脱リン酸活性に差がないこと を知った。

以上のことから馬鈴薯澱粉をはじめとして根茎澱粉の 完全加水分解にはアミラーゼのほか, ホスファターゼの 存在が必要であることが判明したので, このホスファタ

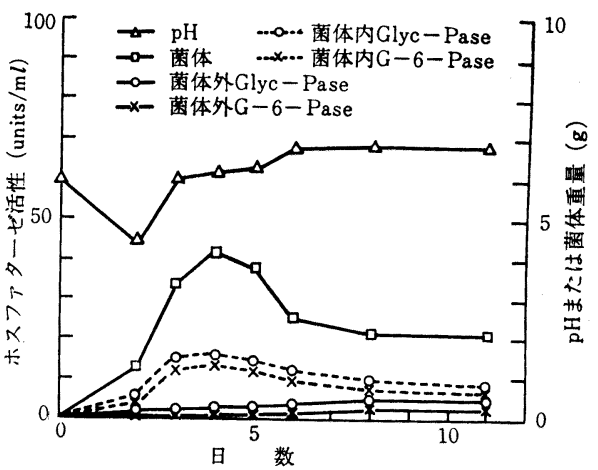

第 10 図 $68 \mathrm{mgP} / 100 \mathrm{ml}$ 培地でのホスファターゼ の生産

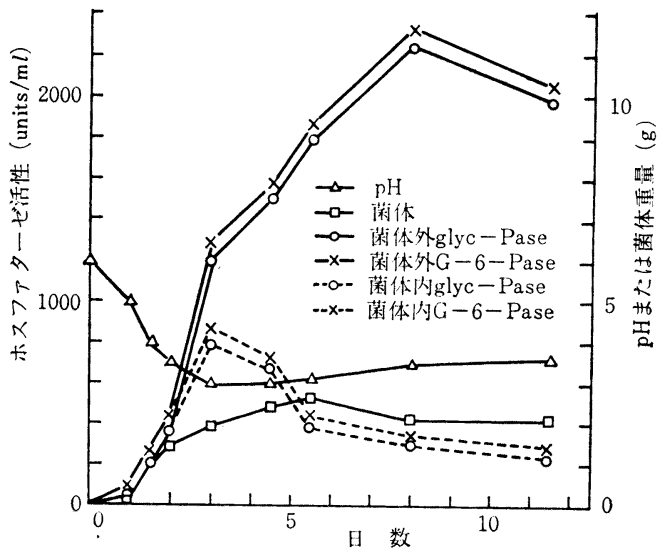

第 11 図 $1 \mathrm{mgP} / 100 \mathrm{ml}$ 培地でのホスファターゼ の生産

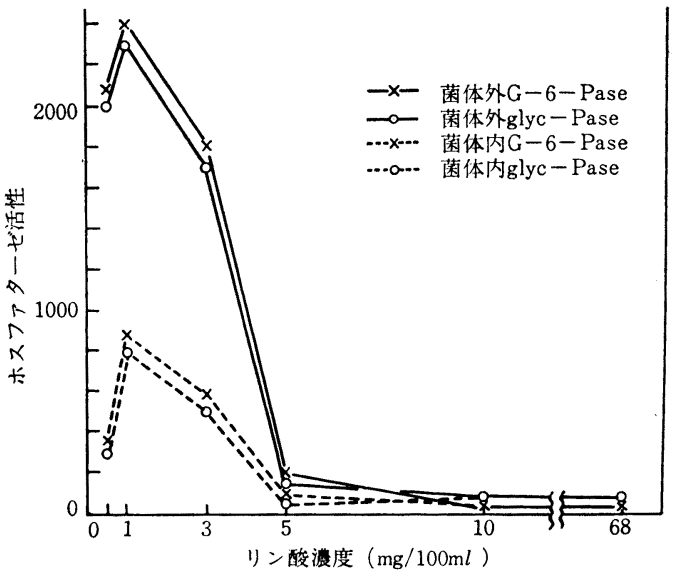

第 12 図培地中のリン酸濃度と生産されるホスフ アターゼ活性

一ゼを工業生産を目標に大量生成の研究を行なった。培 地中の無機リン酸含量を少なくすることによって酸性ホ スファターゼが多量に生産されることが酵母 ${ }^{15,16,17) て ゙, ~}$ 

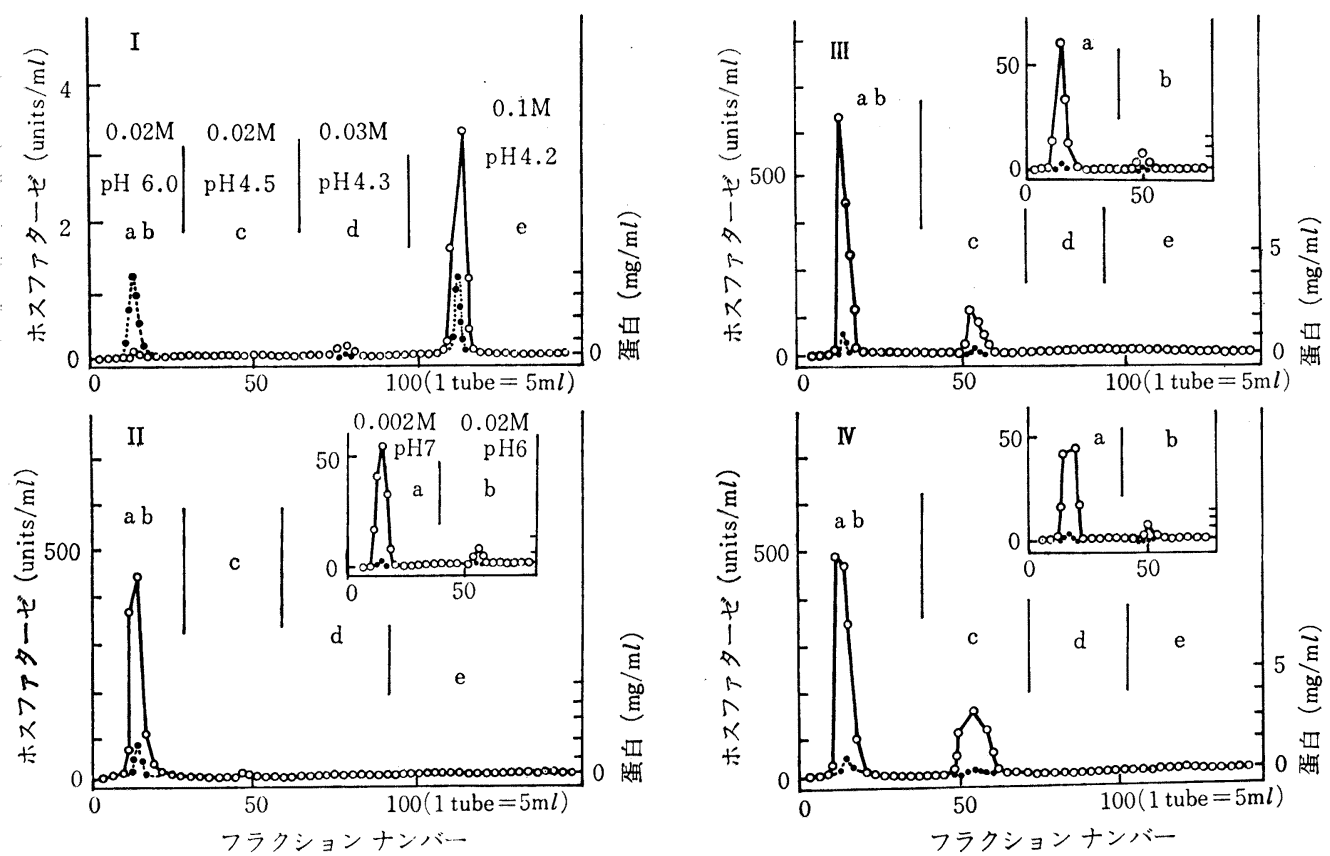

第 13 図 菌体外ホスファターゼの DEAE-セルロースカラムクロマトグラフィー

I $68 \mathrm{mgP} / 100 \mathrm{ml}$ 培地 6 日培憼

III $3 \mathrm{mg} \mathrm{P} / 100 \mathrm{~m} l$ 培地 7 日培

II $3 \mathrm{mgP} / 100 \mathrm{ml}$ 培地 4 日培娄

IV $3 \mathrm{mgP} / 100 \mathrm{~m} l$ 培地 11 日培耤

またアルカリ性ホスファターゼについては Escherichia coli ${ }^{18,19,20)}$ および Neurospora crassa ${ }^{21)}$ に拈いて報告 されている。

黑橧菌 Aspergillus awamori var. kawachii に打い ても培地中のリン酸含量を減少することによってホスフ アターゼが著量に生産されるか否か検討した。正常の振 璗培養用培地 $(68 \mathrm{mgP} / 100 \mathrm{ml})$ では第 10 図に示される ように微量のホスファターゼしか生産されないが, リン 酸含量を減少するとともにホスファターゼ生産量は増加 し, 0.5 1. $0 \mathrm{mgP} / 100 \mathrm{ml}$ の培地では正常培地の約 200 倍におよぶホスファターゼが生産されだ22)。(第 11 図) 培地中のリン酸含量と生産ホスファターゼ量の関係を図 示すると第 12 図の通りで, $1.0 \mathrm{mgP} / 100 \mathrm{ml}$ 培地がもっ ともホスファターゼの生産が大きいことがわかる。

さて,このようにリン酸含量の少ない培地ではホスフ アターゼが著量に生産されることがわかったが,このよ うにして生産されたホスファターゼの性質が正常培地で 生産されるものと異なるかどうか検討した。第 13 図か ら明らかなように, $68 \mathrm{mgP} / 100 \mathrm{ml}$ の正常培地でのホス ファターゼは DEAE-セルロースカラムで $0.1 \mathrm{M}$ 塩酸-

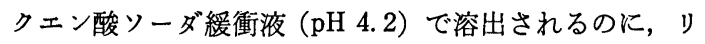
ン酸含量の少ない培地で生産されるホスファターゼは

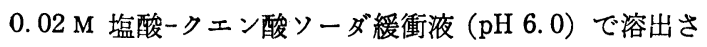
れる。その至適 $\mathrm{pH}$ も前者が $\mathrm{pH} 3.5$ 付近であるのに, 後者では $\mathrm{pH} 5.0$ 付近にあった。また加えるリン酸の種

第 6 表 エステラーゼ生産へのリン酸エステルの種 類の影響

\begin{tabular}{|c|c|c|c|c|c|c|}
\hline \multirow{2}{*}{ 培地 リン酸源 } & \multirow{2}{*}{$\begin{array}{l}\text { 培地中り } \\
\text { 浱度 } \\
\mathrm{mg} / \\
100 \mathrm{~m} l\end{array}$} & \multirow{2}{*}{$\mid \begin{array}{l}\text { 醮素の } \\
\text { 型 }\end{array}$} & \multicolumn{4}{|c|}{ エステラーゼ活性 } \\
\hline & & & 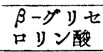 & 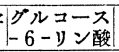 & リボ核酸 & フィチン \\
\hline 無機 リン酸 & 68 & \begin{tabular}{|l|} 
菌体外 \\
菌体内 \\
\end{tabular} & $\begin{array}{r}5.5 \\
6\end{array}$ & $\begin{array}{l}4.2 \\
5.5\end{array}$ & $\begin{array}{r}33 \\
7\end{array}$ & $\begin{array}{r}1.5 \\
1\end{array}$ \\
\hline 無機 リン酸 & 3 & \begin{tabular}{|l|} 
菌体外 \\
菌体内
\end{tabular} & $\begin{array}{l}450 \\
240\end{array}$ & $\begin{array}{l}525 \\
266\end{array}$ & $\begin{array}{r}2,790 \\
273\end{array}$ & $\begin{array}{l}300 \\
265\end{array}$ \\
\hline フィチン & 3 & \begin{tabular}{|l|} 
菌体外 \\
体内
\end{tabular} & $\begin{array}{l}525 \\
230\end{array}$ & $\begin{array}{l}675 \\
320\end{array}$ & $\begin{array}{r}1,260 \\
263\end{array}$ & $\begin{array}{l}325 \\
100\end{array}$ \\
\hline リボ核 酸 & 3 & \begin{tabular}{|l|} 
菌体外 \\
菌体内
\end{tabular} & $\begin{array}{l}375 \\
210\end{array}$ & $\begin{array}{l}450 \\
240\end{array}$ & $\begin{array}{r}1,580 \\
636\end{array}$ & $\begin{array}{l}375 \\
200\end{array}$ \\
\hline $\begin{array}{l}\text { グルニース } \\
-6-\text { ン酸 }\end{array}$ & 3 & \begin{tabular}{|l|} 
菌体外 \\
菌体内
\end{tabular} & $\begin{array}{l}750 \\
212\end{array}$ & $\begin{array}{l}950 \\
230\end{array}$ & $\begin{array}{r}1,950 \\
295\end{array}$ & $\begin{array}{l}350 \\
160\end{array}$ \\
\hline
\end{tabular}

類によって生産されるホスファターゼの種類がかわるこ とはなかった。(第 6 表)このように培地中のリン酸含量 の少ない場合に著量に生産されるホスファターゼは $\mathrm{pH}$ 5.0 付近に至適があるので, Rhizopus 属グルコアミラ 一ゼ, Aspergillus oryzae のグルコアミラーゼなどによ る根茎澱粉の分解にに適していると思われる。最近, 北海 道地方で馬鈴薯澱粉からのグルコース製造に, Rhizopus 属のグルコアミラーゼを使用した場合含りンデキストリ ンが生成され，グルコースの製造歩合が不良とか聞いて いて,このような場合にこのようなホスファターゼの応 用がのぞましい。また第 6 表から明白なように，このホ スファターゼは米, 主として米糠中に存在するフィチン のリン酸を取り払って酵母の栄養素であるイノシトール 
を生成する活性（フィターゼ活性）も強力であるので, 清酒醇造に際し，一考すべき酵素と考えられる。

さて呈味成分のイノシン酸やグワニル酸はリボ核酸に 5'ーリボヌクレアーゼを作用して製造することができリ ボ核酸に $3^{\prime}$-リボヌクレアーゼが作用すると呈味のない 成分に分解されることがしられている。さてこの $5^{\prime}-$ ス クレアーゼの 1 種のホスファターゼであるので, $5^{\prime}-$ ヌ クレアーゼの生産に筆者らのリン酸含量の少ない培地で の菌の培養を試みた。5'ーヌクレアーゼ生産菌 Aspergillus quercinus ${ }^{23)}$ の振逿培地のリン酸含量を正常の 68 $\mathrm{mgP} / 100 \mathrm{ml}$ から次第にその量を減じてゆくと, 3〜5 $\mathrm{mgP} / 100 \mathrm{~m} l$ の培地で $5^{\prime}$-ヌクレアーゼが急増し, 正常 培地の場合の約 30 倍にも達した(第 14 図), (第 15 図)。 しかしながら, 第 16 図のように, $1 \mathrm{mgP} / 100 \mathrm{ml}$ の培 地では $3^{\prime}$-ヌクレアーゼの活性が $5^{\prime}$-ヌクレアーゼ活性 以上に増大し, $3 \mathrm{mg} \sim 5 \mathrm{mgP} / 100 \mathrm{ml}$ の培地が $5^{\prime}$-ヌク レアーゼ生産には最適のリン酸濃度であることが明白に なった。第17図のように，5'-ヌクレアーゼと $3^{\prime}$-ヌクレ アーゼの分離には DEAE-セルロースカラムが大変有効 であった。

以上要するに黑䴴菌 Aspergillus awamori var.

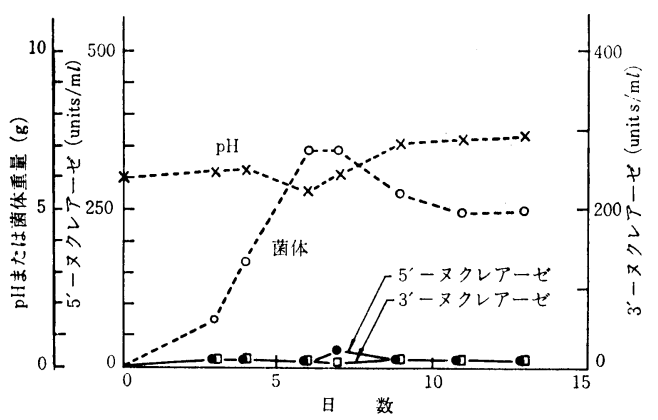

第 14 図 $68 \mathrm{mgP} / 100 \mathrm{ml}$ 培地での $5^{\prime}$-ヌクレアー ゼの生産

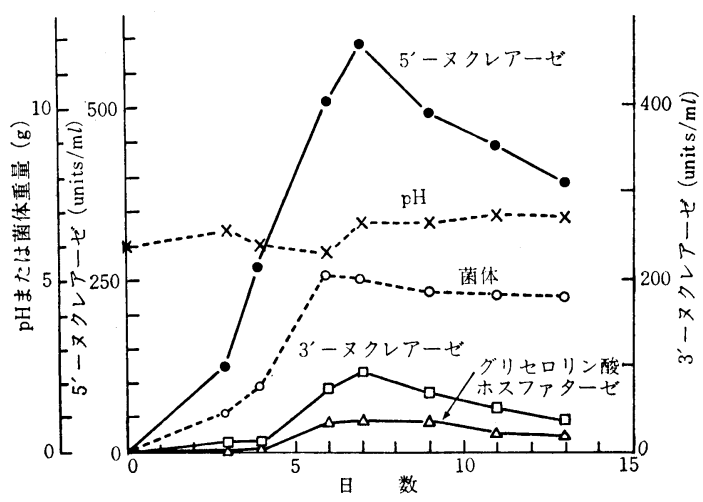

第 15 図 $5 \mathrm{mgP} / 100 \mathrm{ml}$ 培地での $5^{\prime}$-ヌクレアー ゼの生産

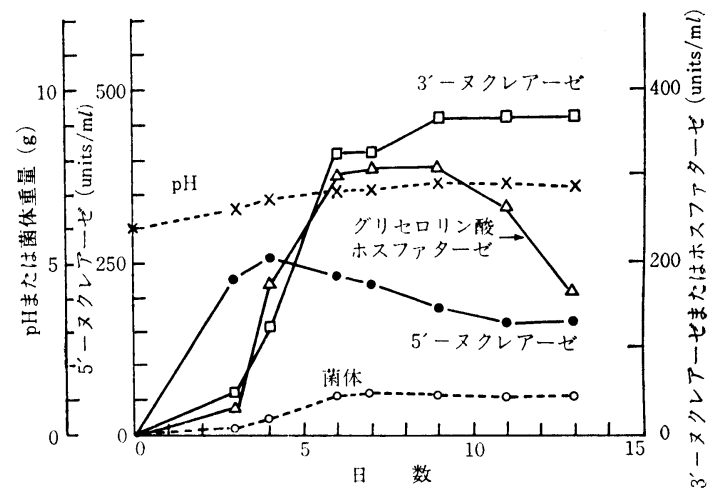

第 16 図 $1 \mathrm{mgP} / 100 \mathrm{ml}$ 培地での $5^{\prime}$-ヌクレアー ゼの生産

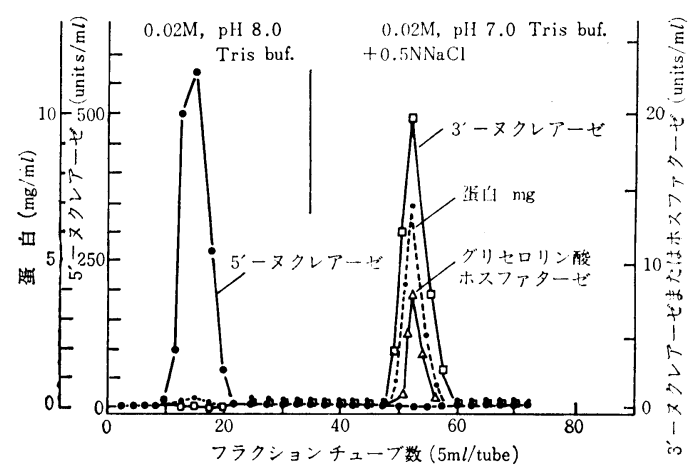

第 17 図 DEAE-セルロースカラムによる 5'-ヌク レアーゼと $3^{\prime}$ ーヌクレアーゼの分離

kawachii のアミラーゼ系による澱粉 分解の研究から次 のことがわかった。

（1）根茎澱粉の完全加水分解にはアミラーゼへのホ スファターゼの共同作用が必要である。

（2）黑药菌の生産するホスファターゼはグルコース 重合度 (DP) 10 以下の含リンデキストリンに作用し, 重合度の小さいデキストリンほど脱リンされやすい。

（3）黑获菌をリン酸含量の少ない培地で培養すると, 多量のホスファターゼが生成される。

（4）リン酸含量の少ない培地で $5^{\prime}$ ーヌクレアーゼ生 産菌の Aspergillus quercinus を培養すると著量の $5^{\prime}-$ ヌクレアーゼが生成された。

略字：グルコース重合度 ; $\overline{\mathrm{DP}}$

グルコースー6-リン酸ホスファターゼ; G-6-

Pase

ßーグリセロリン酸ホスファターぜ；glyc-Pase

考文 献

1) M. SAmec, M. Minaeff and N. Rouzine : Kolloid-Beihefte 19. 203(1924)

2) M. SAMEC, and R. KLEMEN : Kolloid-Beihefte 33, 254(1931) 
3) T. Posternak : Helv. Chim. Acta, 18, 1351(1935)

4) T.Posternak : J. Biol. Chem., 188, 317(1951)

5) T. J. Sсносн : J. Am. Chem. Soc., 64, 2957(1942)

6) T.FukuI : Memoirs of Inst. Sci. and Research, Osaka Univ., 15, 201(1958)

7) K. H. MEYER : Advance in Carbohydrate Chemistry, 3, 302(1948)

8) S. Hizukuri, S. TABATA, and Z. Nikuni : Stärke, 22, 338 (1970)

9) S. Ueda : Bull. Agr. Chem. Soc. Japan, 20, 148(1956)

10) I. YAMAZAKI, S. UEdA, S. HAYASHidA and S. KAYASHIMA : J. Ferm. Tech., 47, 753(1969)

11）上田諴之助：日费化，38，281(1964)

12) M.A.Swanson : J. Biol. Chem., 184, 647(1950)

13) Y. OHTA and S. UEDA : Stärke. 19, 327(1967)

14) Y. OHTA and S. UEDA : Stärke. 19, 363(1967)
15) C. F. Heredia, F. Yen and A. Sols : Biochem. Biophys. Res. Commun., 10, 14(1963)

16) A. Rothstein and R. Meier : J. Cellular Comp. Physiol., 34, 97(1949)

17) G. Schmidt, D. Seraidarian, L. M. Greenbaum, M.D. Hickey and S.J. Thanhauser : Biochim. Biophys. Acta, 20, $135(1956)$

18) B. Hofsten : Biochim. Biophys. Acta, 48, 171(1961)

19) T. HORIUCHI, S. HoRIUCI and D. Mizuno : Nature, 183, 1529(1959)

20) A. Toriani : Biochim. Biophys, Acta, 38, 460(1960)

21) J. F. Nuc, R. J. Dadmer and B. J. Crocken : J. Biol. Chem., 241, 1468(1966)

22) Y. OHTA, K. IKedA and S. UedA : Applied Microbiol., 16 973(1968)

23) Y. ОhтA and S. UedA : Applied Microbiol., 16, 1293(1968)

<書評 $>$

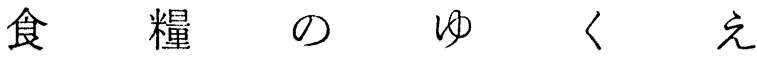

二十一世紀への提言

宮川東一編著

B 6 版 $/ 269$ 頁 /定価 1,200 円/発行所(株)柴田書店

第 1 に感ずることは, 本書は極めてまとすに食糧問題 を追究していることである。世に氾濫していることあれ かしのオーバーな時局便乗型とは違い, 多くの資料と冷 静な思考を駆使して, 問題を深く掘り下げている。

有吉女史の「複合污染」はベストセラーであったと か。併しそこにいら無農薬, 有機農業による農産物, 添 加物なしの加工食品をロにすることができるのは, 確か に貲沢なエリートだということになろう。

狭く資源の乏しい日本に，一億の国民がまがりなりに も豊かに暮していくためには, 流通の合理化すさること ながら, 食品保存料, パッケージの使用は何といっても 必要である。それが安全であるべきことはいうまであな
いが，見せかけを良くするための着色料などとは区別し て論ずべきである。

鬼に角米だけが自給率 100\%であり，それる変な農政 によって世界相場の倍以上もの高い值段で売買されてい るのが現実の日本の姿である。まさに目前の利害に眩惑 されることなく，目を大きく世界に見開いて，次世代の ためにも何らかの手を打つべきときである。

因に目次を紹介すると，

日本人の食糧は当面大丈夫なのか。これからどらなる 〈その $1>，\langle そ の 2>$ 。食糧の国内流通体制は合理的 か。消費者の購買態度と小売業界の課題。未来の食品。 といらことになる。 